\title{
Creative Cartography: From the Arabian Desert to the Garden of Allah
}

\author{
Holly Edwards
}

Rendering a particular place and its inhabitants will always be a reductionist process. ${ }^{1}$ Words can never fully capture the experience of being there in person, subject to light and wind, heat and sound, conversation and even conflict. The somatic reality, affective impact, and social engagement are hard to convey across social, political, and cultural time and space; personal perspective, after all, is unique and things get lost in translation. This is especially true for a much-storied region like the "Orient." And what about images-might they work better than words? Surely, un manipulated photographs capture places and people legibly. Alternatively, a skilled painter can observe and depict the real world with compelling verisimilitude. One might simply call such image-making "art," but, like any good cover story, a great picture works on multiple levels: it commands attention with beauty or spectacular surface effects and then it tells a good tale. The challenge is to get beyond the headlines and the images that accompany them.

My rhetorical foil of the "cover story" suggests that this project entails looking at text/image relationships, ${ }^{2}$ and it will. But the phrase is also

1 I would like to thank my colleagues at the Francis Oakley Center for the Humanities, Williams College, for their critical reading of a draft of this project. I also thank Kailani Polczak, Williams College, for her expertise and generosity on all things Hawaiian.

2 Such relationships have garnered insightful attention in Orientalism studies. See, for instance, Wendy M.K. Shaw, "Between the Sublime and the Picturesque," in The Poetics and Politics of Place, ed. Zeynep Inankur, Reina Lewis, and Mary Roberts (Istanbul: Pera Museum, 2011), 115-26. Other issues related to ekphrasis and image/word relationships meant to uncover a deeper process that I term "creative cartography" - i.e., mapping, picturing, and narrativizing the world around and through self/other, here/there, and now/then. ${ }^{3}$ That "self" might be a single person, a community, or a nation; the setting that results will depend on how the participants wield artifacts, information, and images over time and space. For those participants, of course, it is the world, realistically rendered, engaged, and crafted around valued things and performed ideas. Two key players in the story that follows are a French painter and an American lithographer, both of whom depicted a vaguely defined region from diverse perspectives and with access to different source materials. One termed it the Arabian Desert, while the other called it the Garden of Allah. Their lives overlapped implicitly, indirectly, and distantly, somewhere on the surface of the globe, ${ }^{4}$ and their work offers us vicarious access to that enigmatic place in retrospect.

are covered in Sugata Ray, "Introduction: Translation as Art History," Ars Orientalis 48 (2018): 1-19.

3 The term "creative cartography" is an extension of my prior study, "A Million and One Nights: Orientalism in America, 1870-1930," in Noble Dreams, Wicked Pleasures: American Orientalism, 1870-1930, ed. Holly Edwards (Princeton, NJ: Princeton University Press, 1999), 11-58, though subsequent pertinent scholarship is extensive, especially the "worlding" discourse. E.g. David Trend, Worlding: Identity, Media and Imagination in a Digital Age (Boulder: Routledge, 2013).

4 The so-called "Global Turn" is the backdrop and conceptual context for this case study. Addressing that is beyond the scope of this project but, for present purposes, I cite here a collection of perspectives: Jill H. Casid and Aruna 


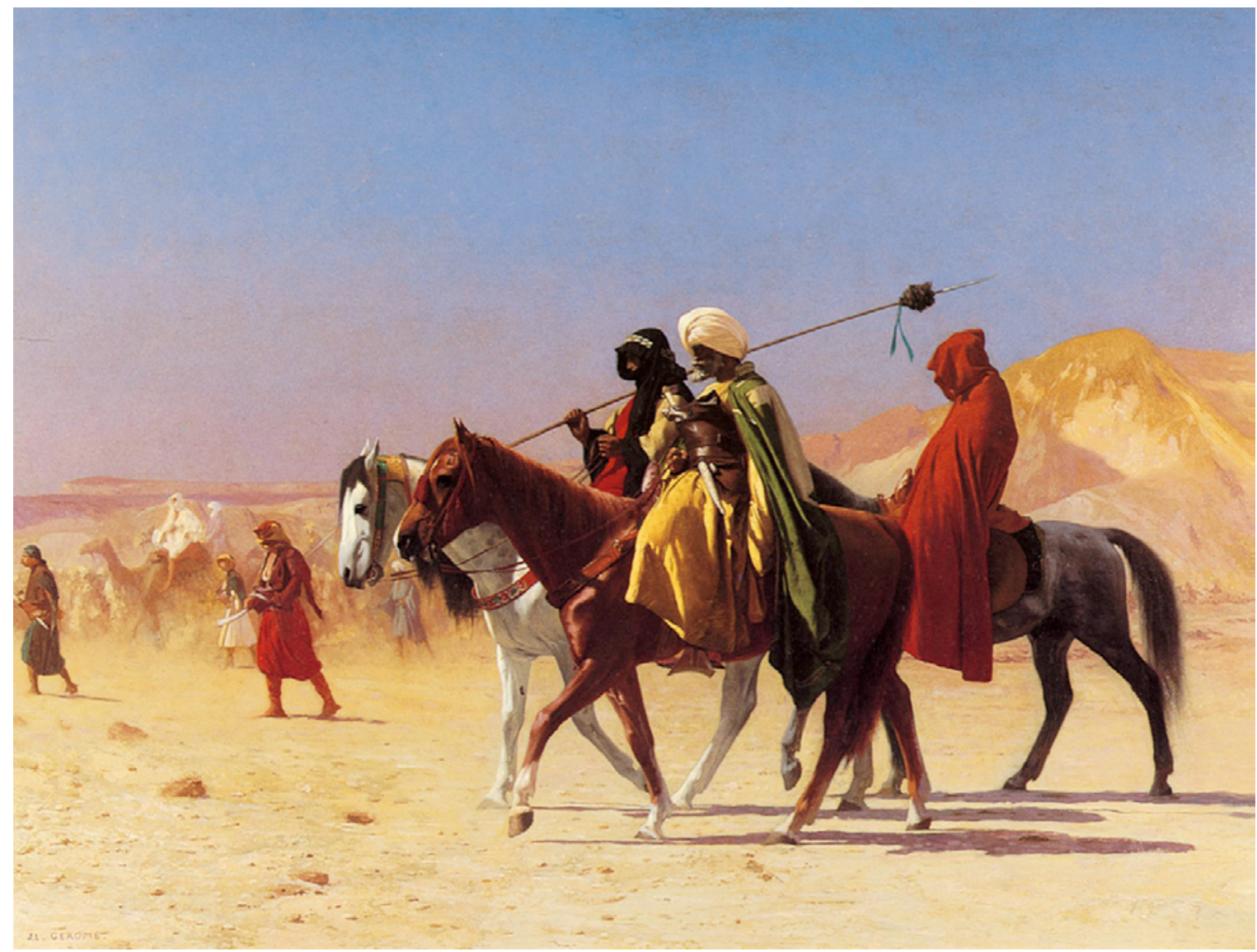

FIGURE 6.1 Jean-Léon Gérôme, Arabs Crossing the Desert, 1870.

My primary sources are archives, objects, and images left behind, but the cumulative discourse is a vexing thing itself, borne of and lodged in the minds of its makers. Such entanglements have wielded very real agency in the world, just as physical artifacts do, ${ }^{5}$ generating a dense palimpsest to excavate, layer by layer. So, let the reader be warned: This argument might appear to meander as I wander from desert to garden, but that is quite purposeful. In so doing, I will traverse a landscape collaged and condensed over time-somewhere between East and West, self and other, now and

D'Souza, eds., Art History in the Wake of the Global Turn (New Haven, CT: Yale University Press, 2014).

5 Ian Hodder, Entangled: An Archaeology of the Relationships between Humans and Things (Malden: Wiley-Blackwell, 2012). then. As this trip unfolds, nations emerge and interact - the United States at the turn of the twentieth century and oil-rich Arab countries at the turn of the twenty-first century-even as modernization transpires at varying paces around the world. I recount this journey in an interrogative, exploratory fashion on the premise that retrospect is often selective and even creative.

Two cover stories offer insight into this claim. $A r$ abs Crossing the Desert (fig. 6.1) graces Gerald Ackerman's catalogue raisonné of the nineteenthcentury French painter, Jean-Léon Gérôme. ${ }^{6}$ An

6 Gerald M. Ackerman, The Life and Work of Jean-Léon Gérôme with a Catalogue Raisonné (London: Sotheby's, 1986). The painting has been exhibited and/or published frequently. Two key places are Roger Benjamin and Mounira Khemir, eds., Orientalism: Delacroix to Klee (Sidney: Art 


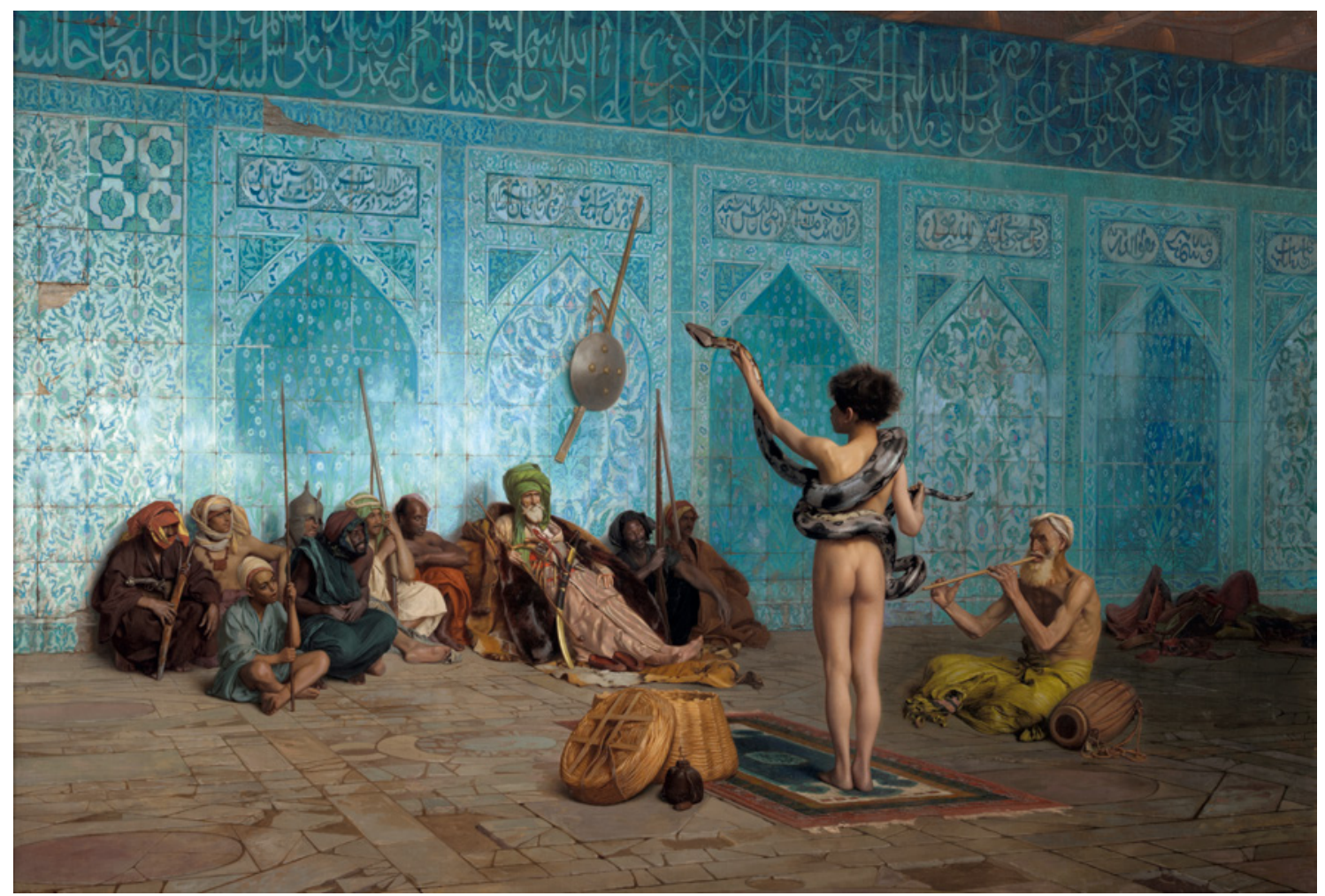

FIGURE 6.2 Jean-Léon Gérôme, The Snake Charmer, 1879.

unsurprising choice for the art historian, the image is indicative of both the artist's virtuosity and his sustained engagement with a vast, arid region. A second deployment of Gérôme's workthe appearance of his painting, The Snake Charm$e r^{7}$ (fig. 6.2), on the cover of Edward Said's Orientalism - consolidates the painter's centrality in any discussion of that place, however obscure its character, location, and boundaries. These two reproductions epitomize what art historian Linda Nochlin termed "the imaginary Orient," even as they manifest a now self-perpetuating scholarship

Gallery of New South Wales, 1997), 105, and Laurence des Cars, Dominique de Font-Réaulx, and Édouard Papet, eds., The Spectacular Art of Jean-Léon Gérôme (Los Angeles: Skira, 2010), 238-39.

7 Sophie Makariou and Charlotte Maury, "The Paradox of Realism: Gérôme in the Orient," in Cars, Font-Réaulx, and Papet, The Spectacular Art of Jean-Léon Gérôme, 278-89. in the wake of Said's publication. ${ }^{8}$ Images of nude bodies, sensational settings, and dramatic

8 Orientalism discourse is vast and tangled. For this project and art historians, in particular, the foundational study is Linda Nochlin, "The Imaginary Orient," in Politics of Vision: Essays on Nineteenth-Century Art and Society (New York: Harper and Row, 1989), 33-59. For general overviews of the conceptual scope, roots, and evolution of the concept, see Alexander Lyon Macfie, Orientalism: A Reader (New York: New York University Press, 200o); Zachary Lockman, Contending Visions of the Middle East: The History and Politics of Orientalism (Cambridge: Cambridge University Press, 2004); and François Pouillion and Jean-Claude Vatin, eds. After Orientalism: Critical Perspectives on Western Agency and Eastern Re-Appropriations (Leiden: Brill, 2011). Of particular synthetic and place-specific importance is Mary Roberts, Istanbul Exchanges: Ottomans, Orientalists, and Nineteenth-Century Visual Culture (Oakland: University of California Press, 2015). Current comments prompted by the anniversary of Said's publication include Nasser Rabbat, "The Hidden Hand: Edward Said's Orientalism and Architectural History," Journal of the Society of Architectural 
swashbuckling led scholars to identify and reify tropes of eroticism, despotic force, and exotic behavior, thereby corroborating Said's thesis of colonial power and condescension with visual evidence. Such patterns of representation have been further nuanced with reference to the identity and nationality of individual artists, different mediums of expression, collective versions, and internalized iterations. As I will elaborate further below, what was once deemed binary and hierarchical is now appreciated as multi-centric, interactive, and heterochronic. ${ }^{9}$ While much critical scholarship has focused on cultural encounters and exchanges transpiring in and around the Ottoman sphere, comparable processes have unfolded around other centers of political gravity and a wide range of material evidence, thereby disrupting geographies and enriching the study of globalizing visual culture. ${ }^{10}$ The following chapter is a case in point, distinguished by its winding path-from "Arabia" to Hawaii to Washington D.C.- - and its disparate sources-from painting and photography to theater and public performance. So, what does all that look like?

Historians 77, no. 4 (2018): 388-89, and Zeynep Çelik, "Reflections on Architectural History Forty Years after Edward Said's Orientalism," Journal of the Society of Architectural Historians 77, no. 4 (2018): 381-87.

One of several examples of deploying the concept within the "Orient" itself is Ussama Makdisi's "Ottoman Orientalism," American Historical Review 107, no. 3 (2002): 768-96. Further revisionist issues were covered in the "Objects of Orientalism" symposium organized by Mary Roberts and Marc Gotlieb in April 29-30, 2016, at Sterling and Francine Clark Art Institute, Williamstown, Massachusetts.

On the notion of disruptive geography and broader horizons see Mary Roberts, Reina Lewis, and Zeynep Inankur, "Introduction: Disruptive Geographies," in The Poetics and Politics of Place: Ottoman Istanbul and British Orientalism, ed. Zeynep Inankur, Reina Lewis, and Mary Roberts (Istanbul: Pera Museum, 2011), 19-29. Sugata Ray's formulation of "entangled web of connected geographies" appears in "Introduction: Translation as Art History," 16.

\section{Picturing the Orient}

To answer this question, I return to my starting point-Gérôme's painting - to dive more deeply into the artist's practice and his results. Touted as "realism" in comparison with other modes of rendering the "Orient," such as Romanticism, Impressionism, or Aestheticism, ${ }^{11}$ his work seems to offer compelling journalistic veracity. That verisimilitude, however, has rightly been deemed paradoxical. Cumulative study of The Snake Charmer, for example, has demonstrated that the painting is actually a pastiche of accurately rendered elements which were brilliantly but creatively merged into a contrived whole. ${ }^{12}$ The tilework, drawn (and somewhat rearranged) with the help of photographs back in the studio, derives from a palatial setting that would never have hosted such a gathering. The clothing that the actors wear and the artifacts that are displayed are equally incongruous. Still, it is riveting false advertising - the quintessential cover story for documenting the "Orient."

That Gérôme mined the work of contemporary photographers for raw material has already been documented; that there was plenty of material available is also clear. ${ }^{13}$ However, what the artist

11 On the stylistic sequencing and the realism debate at the time see Benjamin and Khemir, Orientalism: Delacroix to Klee, 7-31. On different motivations to depict the Orient see Tim Barringer, "Orientalism and Aestheticism," in Inancur, Lewis, and Roberts, The Poetics and Politics of Place, $243^{-5} 8$.

12 Cf. Mary Roberts, "Gérôme in Istanbul," in Reconsidering Gérôme, ed. Scott Allan and Mary Morton (Los Angeles: J. Paul Getty Museum, 2010), 119 and note 3.

Ibid., 119-31. See also Mounira Khemir, "The Orient in the Photographers' Mirror: From Constantinople to Mecca," in Benjamin and Khemir, Orientalism: Delacroix to Klee, 188-98; Nancy Micklewright, "Orientalism and Photography," in Inancur, Lewis, and Roberts, The Poetics and Politics of Place, 99-114. Indigenous photographers are a critical subset that has engendered an important and mushrooming discourse of its own. E.g. Ali Behdad, "Mediated Visions: Early Photography of the Middle East and Orientalist Network," History of Photography 41, no. 4 (2017): 362-75; Zeynep Çelik and Edhem Eldem, Camera Ottomana: Photography and 
did was not just a matter of appropriative copying. His willingness to undertake arduous travel and seek out "direct engagement with the physical world"14 was also critical to the optical verisimilitude that he achieved in paint. Indeed, the artist's virtuosity, a product of embodied experience, assiduous study, and incisive synthesis of the available materials, is evident in both The Snake Charmer and Arabs Crossing the Desert; in the latter, for instance, the viewer feels the light and heat of the desert though the image might hang in a gilt frame on a museum wall.

It is important, moreover, to situate this "realism" diachronically, both at the moment of contextualized production and then in retrospect, as subsequent patterns of consumption emerge. In the nineteenth century, accelerated mobility and increased tourism generated amplified desire to document these terrains of broadening horizons. Thanks to improved modes of travel (e.g., Ottoman rail, Mediterranean steamship), many people were traversing land and sea, with cascading ramifications for the crafting of self, depiction of others, and the formation of communities, institutions, and nations. Moreover, Western travelers were not the only ones wielding paint brushes or cameras. Indigenous image-makers were also rendering homelands and neighbors - i.e., the "Orient" - from embedded proximity with very cosmopolitan perspectives, thereby blurring boundaries and transposing the binary of self and other into a multi-centric,

Modernity in the Ottoman Empire, 1840-1914 (Istanbul: Koç University Publications, 2015); and Ali Behdad and Luke Gartlan, eds. Photography's Orientalism (Los Angeles: Getty Publications, 2013).

14 Peter Benson Miller, "Gérôme and Ethnographic Realism at the Salon of 1857," in Allan and Morton, Reconsidering Gérôme, 108. On realism more generally, see Roger Benjamin, Orientalist Aesthetics: Art, Colonialism, and French North Africa, 1880-1930 (Berkeley: University of California Press, 2003), 23-31. On somatic experience and its interpretation, see Marc Gotlieb, "Figures of Sublimity in Orientalist Painting," Studies in the History of Art 74, Symposium Papers LI: Dialogues in Art History, from Mesopotamia to Modern: Readings for a New Century (2009): 316-41. visualized arena. ${ }^{15}$ Additionally, technologies of reproduction made it possible to turn unique paintingsinto more shareable experience, with the result that the sheer volume of images mushroomed. ${ }^{16}$

As outsiders, insiders, transplants, migrants, and proliferating image-makers assembled, scholarly rhetoric around "Orientalism" has responded to address nation-specific iterations and indigenous manifestations. ${ }^{17}$ Inevitably, the nuances proliferate. For example, an entrepreneurial individual might try to capitalize on a stereotype in answer to the prevailing market, while a gifted painter might aspire to master transnationally-lauded style and craftsmanship. Political boundaries do not necessarily determine the activities of enterprising artisans. What kind of Orientalism is it when a Turkish painter learns his craft in Paris and returns home to paint his fellow citizens? ${ }^{18}$ What sort of picture results when a Persian photographer renders a familiar trope like the snake charmer encountered

15 Indigenous image-makers blur boundaries of artist/patron/power in provocative ways. E.g. Aykut Gürçağlar, "The Dragoman Who Commissioned His Own Portrait," in Inankur, Lewis, and Roberts, Poetics and Politics of Place, 210-19.

16 The discourse surrounding mass-produced imagery in the nineteenth century is beyond the scope of this project. For present purposes, see Roberts, Istanbul Exchanges, 88-89, and 105, and Emerson Bowyer, "Monographic Impressions," in Allan and Morton, Reconsidering Gérôme, 22-39.

17 French Orientalism, the paradigmatic case, has been supplemented with other studies, e.g.: Nicholas Tromans, ed., The Lure of the East: British Orientalist Painting (London: Tate, 2008); Claudia Hopkins, "The Politics of Spanish Orientalism: Distance and Proximity in Tapiró and Bertuchi," Art in Translation 9, no. 1 (2017): 134-67; and Suzanne Marchand, German Orientalism in the Age of Empire (New York: Cambridge University Press, 2009).

18 See Edhem Eldem, "Making Sense of Osman Hamdi Bey and His Paintings," Muqarnas 29 (2012): 339-83, and Renata Holod and Robert Osterhout, Osman Hamdi Bey and the Americans (Istanbul: Pera Museum Publications, 2011). 
on the street where he lives? ${ }^{19}$ Might a neighbor become an other over time? Or, might an other become a compatriot, with the passage of time or the changing of borders? ${ }^{20}$ In cases like these, the lives and perspectives of particular image-makers override glib boundaries of other, trope, culture, and nation. As I reference this "thing" called Orientalism, then, I hope to maintain a mindful oscillation among individuals and morphing collectives, and an appreciation of the agency of the art therein. In the words of Talinn Grigor, "[ $t$ ] he other is never outside us; it is this search for the other in us and us in the other that renders art-historical undertakings, regardless of localities, global."21

Retrospective narrative, then, is no small challenge. The lived present is instantly gone, but the physical evidence of the past remains. The things that we craft, find, cherish, and historicize define that which we call self and, by extension, community or nation. Millennial curation is a particularly challenging site of mapping time and space for diverse audiences. ${ }^{22}$ Making, viewing, sharing, and owning art or artifacts are modes of place-making and identity fashioning and how that material works to shape worlds depends on who holds the evidence and who is telling the story.

19 Ali Behdad, Camera Orientalis: Reflections on Photography of the Middle East (Chicago: University of Chicago Press, 2015), and Aphrodite Desiree Navab, "To Be or Not to Be an Orientalist? The Ambivalent Art of Antoin Sevruguin," Iranian Studies 35, no. 1/3 (2001): 113-44. Cf. Ella Shohat, "On Orientalist Genealogies: The Split Arab/Jew Figure Revisited," in The Edinburgh Companion to the Postcolonial Middle East, ed. Anna Ball and Karim Mattar (Edinburgh: Edinburgh University Press, 2018), 118-59.

Talinn Grigor, "What Art Does: Methodological Privileging of Agency and Art History's Global Dispute in 1901," in Casid and D'Souza, Art History in the Wake of the Global Turn, 140.

Cf. Christine Riding, "Staging The Lure of the East: Exhibition Making and Orientalism," in Inankur, Lewis, and Roberts, The Poetics and Politics of Place, 33-46.

\section{Owning the Pictures}

I return now to my first cover stories to probe more deeply still. Gérôme's Snake Charmer, owned by the Sterling and Francine Clark Art Institute in Williamstown, Massachusetts, has become the icon of objectifying condescension toward the "Orient" and its inhabitants in the academic community, while Arabs Crossing the Desert is one of the 156 works owned by an anonymous collector from the Arab world. ${ }^{23}$ This apparent dissonance demands attention. If Gérôme's art does demean and essentialize its subjects with some creative duplicity, as many scholars have claimed, that seeming realism also holds the potential to render Arab dignity at a time when nation-states in the Arab world are crafting local identities in global visual culture. The Najd collection of Orientalist painting referred to above was assembled over the 1980 s by a Saudi businessman who trusted French realism/Orientalism to safeguard "the true customs and traditions of the Arab people" in the face of rapid modernization. ${ }^{24}$ And he is not the only one who has done so.

Roger Benjamin tracked the longevity of postcolonial taste to articulate how Arab collections of this sort have worked to contextualize the present and augur the future, while Nicholas Tromans has explored the issue further, querying the "globalized placelessness" and branding that transpire in transnational consumption. ${ }^{25}$ Mercedes Volait expressed it concisely: "Orientalism has been Orientalized," and the market for such painting in the

23 Caroline Juler, Najd Collection of Orientalist Paintings (London: Manara, 1991).

24 Brian MacDermot, "Introduction: One Man's Choice," in Juler, Najd Collection of Orientalist Paintings, 1.

25 Roger Benjamin, "Post-Colonial Taste: Non-Western Markets for Orientalist Art," in Benjamin and Khemir, Orientalism: Delacroix to Klee, 32-40; Nicholas Tromans, "Bringing It Home? Orientalist Painting and the Art Market," in Inankur, Lewis, and Roberts, The Poetics and Politics of Place, $65^{-76}$, quote p. 70 . 
oil-rich Gulf region simply reflects that change. ${ }^{26}$ Moreover, collections are not confined to gilt framed pictures, nor to a small cadre of wealthy individuals: public institutions reflect similar aspirations. ${ }^{27}$ Such self-fashioning has many iterations, and it is not without precedent, nor is it medium-specific. ${ }^{28}$ With respect to painting, however, it is precisely the "realism" and sheer beauty of the pictures that produce and enshrine a regionalized heritage for Gulf constituencies in vivid and flattering detail. Crafting a preface for the present in this way is often the purpose of the material and visualized past. ${ }^{29}$ As I will explore further below, this might also describe Arab participation in modern museum culture. I base that argument on the conviction that the rich extant archives of Orientalist imagery can sustain multiple curations and work to rectify, claim, or resuscitate history in myriad ways for diverse individual

26 Mercedes Volait, "Middle Eastern Collections of Orientalist Painting at the Turn of the 21st Century: Paradoxical Reversal or Persistent Misunderstanding?" in Pouillon and Vatin, After Orientalism, 258.

See Karen Exell, "Desiring the Past and Reimagining the Present: Contemporary Collecting in Qatar," Museum and Society 14, no. 2 (2016): 259-74; "Doha's Cultural Armature on Display: A Response to Artifacts and Alegliances: How Museums Put the Nation and the World on Display," Identities 24, no. 1 (2017): 19-25; "Utopian Ideals, Unknowable Futures, and the Art Museum in the Arabian Peninsula," Journal of Arabian Studies 7, no. 1 (2017), 49-64; and "Collecting an Alternative World: The Sheikh Faisal bin Qassim al Thani Museum in Qatar," in Cultural Heritage in the Arabian Peninsula: Debates, Discourses and Practices, ed. Karen Exell and Trinidad Rico (Burlington: Ashgate, 2014).

28 Natalie Koch has made the connection to Hobsbawm's "invention of traditions" in regard to falconry in "Gulf Nationalism and Invented Traditions," The London School of Economics and Political Science: Middle East Centre Blog, June 13, 2018, https://blogs.lse.ac.uk/ $\mathrm{mec} / 2018 / 08 / 03 /$ gulf-nationalism-and-inventedtraditions/.

29 Gordon Wood, The Purpose of the Past: Reflections on the Uses of History (New York: Penguin Press, 2008). and collective identities. ${ }^{30}$ If such materials are being mobilized in the millennial present by emerging Arab nations, fledgling countries elsewhere have deployed partialized notions of the Orient as well, albeit decades earlier, for different purposes. Stated otherwise, the Arabian Desert is an extraordinary place, a setting for life and a foil for creative cartography.

\section{$3 \quad$ Going Places, Making Pictures}

So finally, now, I turn from Arabs Crossing the Desert to that other story mentioned in the title to this paper, The Garden of Allah. This second story is about place-making and identity crafting among American citizens, whose images and performative antics are documented in paintings, photographs, souvenirs, and commemorative albums. It is a story rooted in the frontier spirit of the nineteenth century, in which Christian mission was overlaid on Manifest Destiny, and the Middle East was overlaid on the Wild West. As I have argued elsewhere, for painters like Albert Pinkham Ryder, Frederic Remington, Charles Russell, and William Merritt Chase, the Orient served as a template to organize the expanding world they occupied and represent it in vivid, legible terms for their audiences. Russell, for example, bemoaned the disappearing frontier, the Wild West, even as he had his wife masquerade as a Native American woman, posed as a languid odalisque from the harem. ${ }^{31} \mathrm{In}$ effect, stereotypes of the exotic East served as a visioning lens through which to view a different landscape and render it for American audiences.

For self-fashioning case studies outside the Arabian Peninsula, see Costanza Caraffa and Tiziana Serena, eds., Photo Archives and the Idea of Nation (Berlin: Walter de Gruyter, 2015). Regarding complexities within the region, see Karen Exell and Trinidad Rico, “There Is No Heritage in Qatar': Orientalism, Colonialism and Other Problematic Histories," World Archeology 45, no. 4 (2013): 670-85. Holly Edwards, "Catalogue of the Exhibition," in Edwards, Noble Dreams, Wicked Pleasures, 186-87. 
Thus, the world was shrunk to fit a bigger and better United States, a form of creative cartography that I will articulate below.

I begin with Robert Hichens' novel, The Garden of Allah. Written in 1904 and set in the terrain around Biskra, Algeria, ${ }^{32}$ where the author had traveled extensively, ${ }^{33}$ it is a romance between an adventurous English woman named Domini, and an apostate priest, meeting by chance and falling in love. For them, the stifling nature of their own "civilized" societies prompted escape into a more invigorating, untrammeled, "primitive" culture. The desert turns, thus, into a place of refuge and spirituality. As the book's flyleaf declares: "They met by chance but so irrevocably were they bound together that it seemed as if destiny had led them to each other ... and so they journeyed together through the beautiful Garden of Allah to meet a fate they knew they could never escape." 34

Such a description captures the somewhat florid tone of the novel; nevertheless, it went through multiple editions and became a hugely successful Broadway play of the same name. Before I turn to that theatrical rendering, however, it is instructive to consider the life of Robert Hichens (1882-1940), the author of the novel, in hopes of mapping his brand of Orientalism more precisely. ${ }^{35}$ The son of an English preacher, he did not follow in the footsteps of his ecclesiastical father; instead, he traveled and wrote of his adventures. Having set his sights on the Holy Land early on, he traversed North Africa and Egypt, documenting his trips in travelogues which betray a unique brand of spirituality

32 Robert Hichens, The Garden of Allah (New York: Grosset and Dunlap, 1904). Roger Benjamin specifically addresses this place in "Biskra, or the Impossibility of Painting," in Orientalist Aesthetics, $160 \mathrm{ff}$.

33 Robert Hichens, Yesterday: The Autobiography of Robert Hichens (London: Cassel, 1947). Cf. Edwards, "A Million and One Nights," in Edwards, Noble Dreams, Wicked Pleasures, 43-44. For the larger context of British Orientalism, see Tromans, The Lure of the East, and Barringer, "Orientalism and Aestheticism," in Inankur, Lewis, and Roberts, The Poetics and Politics of Place, 243-58. even as they typify the visual culture of his era. Supplemented with color lithographs by Jules Guerin and photographs by Félix Bonfils ${ }^{36}$ and others, Hichens' publications reflect the options and acumen of a talented and enterprising Orientalist travel writer, courting a broadening market. In some respects, Hichens operated in the same vein as Gérôme. Both experienced the Middle East personally and documented it for more sedentary audiences back home. While Gérôme was primarily a painter and Hichens a writer, both capitalized on increasingly sophisticated modes of mechanical reproduction to disseminate the Orient with vivid realism.

In Hichens' case, passages in his beautifully illustrated volumes are germane to understanding that imagined place, "the Garden of Allah." In particular, I turn to his personal travelogue, The Holy Land, published in $1910 .{ }^{37}$ The book begins in Baalbek and ends in Jerusalem, with each chapter dedicated to a particular place in the topography of Abraham. The culmination of the book (and an inspiration for the travel in the first place) was the celebration of Easter at the Holy Sepulchre. Hichens' description of this ritual verges on babbling ecstasy and ends rather abruptly on the last page of the book, as though further verbiage was unnecessary or inappropriate. While Hichens may not have followed in his father's footsteps, he certainly performed his inherited tradition with heartfelt piety. Ironically, in an earlier chapter, "The Spell of Damascus," a different spirituality surfaces. Some of this chapter is quintessential and stereotypical Orientalism:

"An Oriental city of magic called up by a slave of the lamp to realize one's dream of the Orient; a city ethereally lovely, exquisitely Eastern, ephemeral,

\footnotetext{
36 Carney Gavin, The Image of the East: NineteenthCentury Near-Eastern Photographs by Bonfils: From the Collections of the Harvard Semitic Museum (Chicago: University of Chicago Press, 1982). Robert Hichens, The Holy Land (New York: The Century Company, 1910).
} 
to be blown away by a breath like a tuft of thistledown ... Farther off are low, romantic, cinnamon-colored hills melting away into spaces that look like the beginning of the desert-spaces that seem to be trembling gently as watery mirage seems to tremble ghostlike amid the sands. For the desert is very near to Damascus - so near to it that is like a town set in a lovely oasis, a paradise of shade and waters ... through which there sometimes filters a breath from the burning wastes, like a Bedouin passing through a throng of chattering townsfolk."38

Subsequently, the magic of the lamp-dwelling slave works to create a place of ghostlike mirages and desert wastelands with spiritual implications:

"I knew the essence of the wonderful charm of Damascus. It is a garden city touched by the great desert. Under its roses, one feels the sands. Beside its trembling waters one dreams of the trembling mirage. The cry of its muezzins seems to echo from its mosque towers to that most wonderful thing in nature which is 'God without man' .... Its spell is the spell of the desert and the spell of the oasis." ${ }^{39}$

Thus, evocative aspects of the place-the sand, the oasis, and the mosque-have a powerful somatic impact which, in turn, sustains another spell-driven landscape, the one that the heroine Domini eventually occupies in "the Garden of Allah. In effect, Hichens' embodied experience and idiosyncratic spirituality are conveyed through things, smells, and sounds that coalesce as a palpable setting of mysterious beauty.

This telescoping narrative can be tracked from Hichens's autobiography ${ }^{40}$ to the introductory text of the souvenir book wherein the conception and production of the play are described. ${ }^{41}$ That brochure makes it clear that travel, documentation, and sustained engagement with the desert environment contributed to the production of a

\footnotetext{
$3^{8} \quad$ Ibid., 49 and 53 , respectively.

39 Ibid., 85-86.

40 Hichens, Yesterday, 278-87.

41 Robert Hichens, The Garden of Allah: Souvenir Book for the Play (New York: Liebler, 1911).
}

powerful fabrication on stage: "One summer Mr. Tyler, accompanied by Mr. Hichens, Hugh Ford, stage-director, and Edward Morange, scenic artist, spent several months in the heart of the Desert of Sahara, photographing, sketching and purchasing costumes and properties that would help to convey the illusion of the East [emphasis added]." ${ }^{42}$ With appropriated materials in hand, the transposition happens: Biskra becomes Beni-Mora and "those in the great desert itself seem to breathe the spirit of Algeria, and The Garden of Allah proved to be the most magnificent spectacle that had ever been offered American or any other audiences." ${ }^{33}$ In this way, a real place was rendered in a fake setting and granted a new name, which enjoyed substantial independent agency thereafter. Lest one miss the point, an earnest decoding of the metaphorical place is made explicit in Part Three of the souvenir brochure. The play's heroine, Domini,

"thought of the desert as a soul that need to strive no more ... And she, like the Arabs, called it always in her heart the Garden of Allah. For in this wonderful calm, bright as the child's idea of heaven, clear as a crystal with a sunbeam caught in it, silent as a prayer that will be answered silently, God seemed to draw very near to his wandering children. In the desert was the still, small voice, and the still, small voice was the Lord. "44

In the play (again, as described in the souvenir pamphlet), "real Arabs," elaborate tentage, real camels, ${ }^{45}$ faked windstorms, and heartfelt performance brought the story to life. For the era, it was a particularly extravagant production. Indeed, as one critic noted, "[n]o poorer play was ever so magnificently gilded." ${ }^{46}$ On one level and similar

\footnotetext{
42 Ibid., n.p.

43 Ibid.

44 Ibid.

45 Finding real camels for the original production is described in Hichens' autobiography, Yesterday, 282-83.

46 For further context, see Edwards, "A Million and One Nights," in Edwards, Noble Dreams, Wicked Pleasures, 43-44 and footnote 123 . The quote is from the 23 October 1911 issue of The Evening Sun.
} 


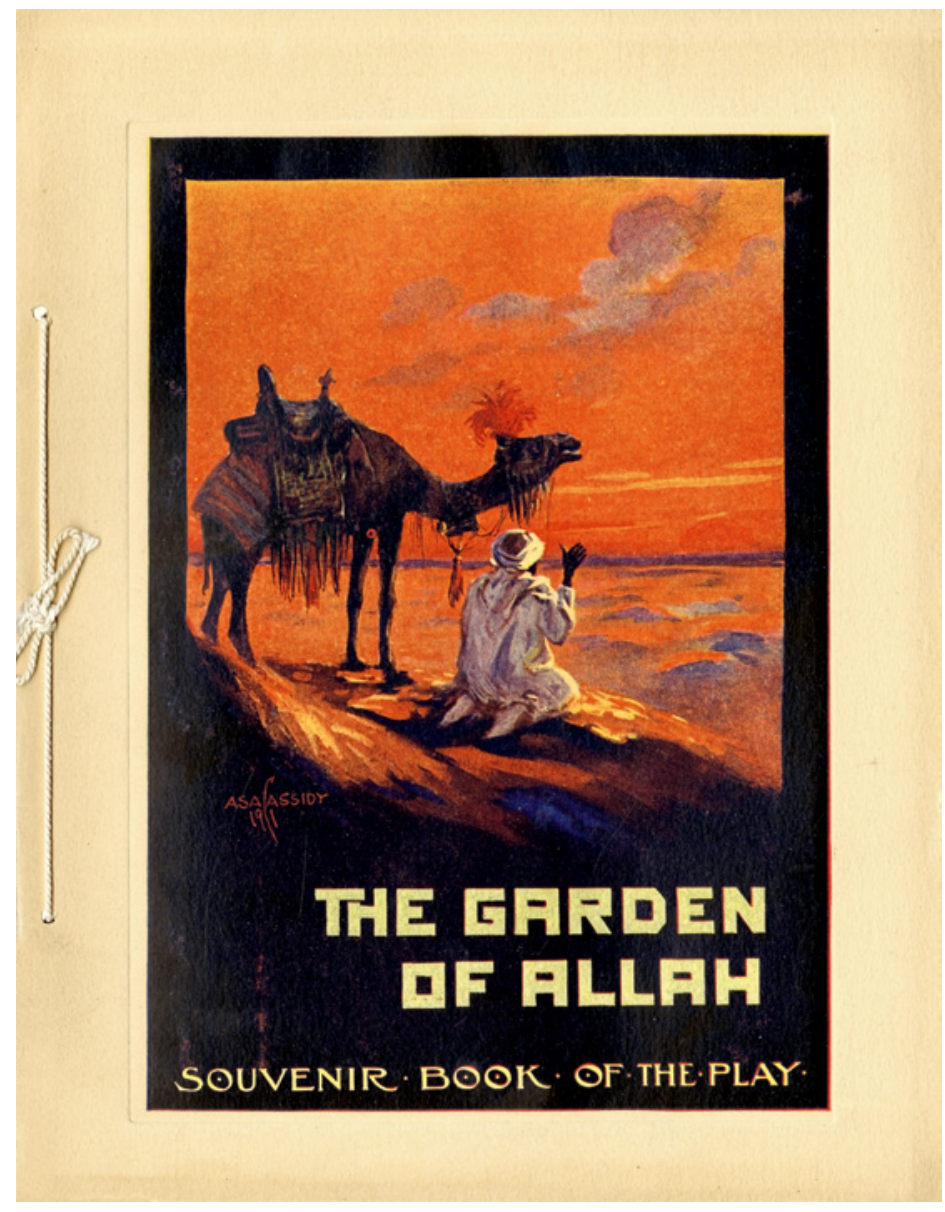

FIGURE 6.3

Robert Hitchens, The Garden of Allah. Souvenir Book of the Play.

NEW YORK. LIEBLER, 1911. to Gérôme's painting, the drama was engaging, palpable realism for avid audiences. In this theatrical iteration, Orientalized spirituality became a vehicle for romance, scandal, and pathos, for which there was a ready market in the United States, particularly in the entertainment industry. Play became film, Hollywood productions mushroomed, and hotel designs housed star-studded fantasy and extravagant indulgence. ${ }^{47}$ Recounting that entire history, however, is not my point here. I turn, instead, to another iteration of the metaphorical place that was first evoked on stage.

For larger context, see Edwards, "A Million and One Nights," 44-53. Regarding hotel architecture and related notorieties, see "The Garden of Allah: A History of the Name," The Garden of Allah, accessed April 1, 2019, https://gardenofallah.com/GOA_original.asp.

\section{Transplanting the Garden of Allah}

The souvenir book of the Broadway play is a fascinating collage which helps reconstruct an ephemeral staging of the "Orient." Indeed, I could dwell at length on the photographs therein, so evocative of early twentieth-century stagecraft, but I want to focus here only on the cover image, a lithograph by American artist Asa Cassidy (fig. 6.3). This picture is reductionist in myriad ways - a broad-stroke rendering of man, camel, and desert, accomplished with limited palette and captioned with the title, The Garden of Allah. The cover thus conjoins two modes of expression-word and image - to identify a particular place, but despite comparable subject matter, it is also radically different from Gérôme's painting, Arabs Crossing the Desert. The obvious dissonance between the two 
raises interesting questions about the artist's intentions. To find out, I would interrogate the lithograph's agency: how does it work and why should we care? The blunt answer is that the image conjures a potent theme with minimalist visual code; it is not a photograph, nor does it deploy optical verisimilitude. Rather, it is evocative shorthand for some thing that had broad and deep appeal for a particular audience.

To identify that audience, it is useful to step back and consider interest groups with Orientalist proclivities that were active at the time. For example, the general taste for theatrical extravagance, manifest in the Broadway moment described above, was shared by other enterprising entrepreneurs, many of whom were members of the Ancient Arabic Order of the Nobles of the Mystic Shrine, a secretive cohort within the larger order of Freemasonry. The backstory is revealing: the guild's instigator, Billy Florence (1831-1891), was an actor and playwright; in 1870, he was in Marseille, France, where he attended a party given by an Arab diplomat that took the form of an elaborately-staged musical comedy, at the end of which the guests became members of a secret society. ${ }^{48}$ That experience, ostensibly reflecting true Arab culture, inspired Florence to undertake similar merry-making back home, in effect forging a reiteration of a fundamentally fanciful affair. Over subsequent decades, Florence and one of his colleagues, Walter Fleming, launched the North American Shrine, which grew considerably in the wake of the Civil War. Its distinctive pageantry was explained with reference to Florence and his professional theatricality: "It is not difficult to see why one as skilled as he was should have selected the picturesque jewels and costumes of the Orientals. The jeweled costumes, the picturesque Arab with his tent, and the holy city of Mecca, together with all that surrounded it and the religion which it

48 This society was ostensibly founded in Mecca by Ali, the son-in-law of prophet Muhammad. typified, naturally appealed to the actor. To him, the whole world was a stage." 49

Acknowledging the performative overlap between Broadway and the Shrine, and the extent to which Arabs, the Arabic language, and Islam figure in the society's activities bears further scrutiny as an index of the "verisimilitude" of its Orientalism. Again, we encounter a cover story of sorts. Certainly, there are abundant references to the Arab world, such as the place names of its meeting centers. Mecca Shrine, for example, held its first formal meeting in New York on September 26, 1872 and Chicago's Medina Temple went public at the Columbian Exposition in 1893. During that seminal event of nation-building, ${ }^{50}$ the Shriners participated in the dedication ceremony for the mosque in the Turkish Village on the Midway Plaisance. Erected by special permission of the Ottoman government, that sanctuary was established with formal ritual but arguably incongruous participants. When the call to prayer was sounded, three thousand people convened, led by a military band; the majority were members of the Shrine, not a local mosque. ${ }^{51}$

These public and private practices were all part of the Shriners' fabricated Arabized identity. In general, the standard greeting among initiates was "Salaam Aleikom" and such declarations as "Allah is great, and the hearts of the true believers are strong ... learn of our mysteries and become, verily a Moslem and true believer." ${ }^{52}$ While this

49 For broader context, see Edwards, "Catalogue of the Exhibition," in Edwards, Noble Dreams, Wicked Pleasures, 218. For the quote, see William B. Melish, The History of the Imperial Council, Ancient Arabic Order Nobles of the Mystic Shrine for North America 1872-1921 (Cincinnati: Abingdon Press, 1920), 10.

$5^{0} \quad$ On this event generally, see Zeynep Çelik, "Speaking Back to Orientalist Discourse at the World's Columbian Exposition," in Edwards, Noble Dreams, Wicked Pleasures, $77-98$.

51 Edwards, "Catalogue of the Exhibition," in Edwards, Noble Dreams, Wicked Pleasures, 217. Charles Chipman, Honolulu: The Greatest Pilgrimage of the Mystic Shrine (s.I., 1901), 28 and 43, respectively. 
might suggest an authentic or substantive connection between the practices of Islam and the convictions of the Shriners, the stance was actually confined to a superficial appropriation of Arabic phrases and behaviors. Shortly after the Columbian Exposition, leaders of the order admitted that, "from an academic standpoint our shrine and our Ritual would be held in ridicule by the savant, or even the progressive student of Arabic learning..." In effect, the Islamic world was reduced to a metaphor, and explained in exoticizing terms: "And of all the lands of mystery, magic, glamour, charm and delight, none excels that of ancient Arabia. Beautiful, strange, colorful, a land of mystery, peculiar customs, yet one of pomp, ceremony, majesty and glory, the ancient courts and civilization of Arabia have stirred the imagination and haunted the dreams of millions." ${ }^{53}$ Rhetoric of this sort suffused the public identity for the guild as the United States came into its own on the world stage.

With diachronic distance, it is possible to gauge the character and the stakes of such theatricality. For the participants themselves, mobilizing stereotypes and Arabic catch phrases in flamboyant parades and other performances was intended to expand Shrine membership and generate community around altruism and active entrepreneurship. ${ }^{54}$ This was evident in the so-called pilgrimages that crossed the country, enabling members of different clubs to travel, meet, and share convivial experience and conviction. In what follows, I will track two caravans that transpired at critical moments in American history-one to Hawaii (1901) and the other from Hawaii to Washington D.C. (1923). Rhetorically mimicking the Muslim hajj ritual, both worked to situate and consolidate the Shrine in American national identity, both

53 Melish, The History of the Imperial Council, 12.

54 Susan Nance, How the Arabian Nights Inspired the American Dream, 1790-1935 (Chapel Hill: University of North Carolina Press, 2009), 12 defined the pertinent patriotic landscape, and both instantiated the United States as a major power in the international arena.

\section{$5 \quad$ Tending and Extending the Garden}

The first caravan began in Washington with considerable formality and was documented in enthusiastic detail in a volume by Charles Chipman entitled Honolulu: The Greatest Pilgrimage of the Mystic Shrine:

"At the meeting of the Imperial Council, held in Washington, D.C., in May, 1900, a dispensation was granted to the Nobles now residing in that newly-acquired garden spot of Uncle Sam's domain (Hawaii) for the formation of a new Temple of the Mystic Shrine... Believing that a pilgrimage to this far-off Oasis would prove to be one of profit as well as pleasure, and that such a visit would tend to cement more closely the ties of brotherly love and affection between the Nobles and Brothers of these two widely separated parts of our Uncle Samuel's growing territory, the Imperial Potentate was pleased to grant their request for a personal visit, granting also to Saladin Temple the distinguished honor of acting as his escort on this most glorious pilgrimage." 55

This paragraph sets the conceptual stage and also betrays a great deal: with its mention of a pilgrimage to the newly-acquired garden spot of Uncle Sam's domain, it signals the entrepreneurial tone, "brotherly" patriotism, and presumed power evident throughout this commemorative volume. That there was already a welcoming enclave in Honolulu is indicative of sustained Masonic activities there; that Hawaii was an "acquisition" bears further scrutiny below. But, first, more can be gleaned from the rhetoric and subsequent passages in the Shriner album.

Chipman, Honolulu, 13 . 
Going west, traveling across the continent aboard the Chicago Limited, was a bold and selfvalidating geography lesson and much care was devoted to the comfort and luxury of the participants along the way: "This wonderful train, the finest in the world, with its electric lights, bath-room, barber shop, stenographer and typewriter (free service), model dining-car, observation car, news agent, conductors, porters and dressing maids, along with other comforts, all combine for the peace and happiness of its patrons." 56 Such train travel, a result of the transformative and ongoing industrialization of the young nation, demonstrated the modernity of the Shriner community in flattering ways. Moreover, while the country was vast and still unevenly settled, American entrepreneurship and cosmopolitan sophistication were deemed evident along the way in the Lind Jewelry Bazaar and the Oriental Hotel in Dallas. ${ }^{57}$ The breadth of the continent and the diversity of its inhabitants were candidly described by the author: whereas Leavenworth, Kansas, is called "a typical town of Prohibition, hatchets and fanatics," Kansas City is "progressive and prosperous, the New York of the Southwest." ${ }^{2}$ When the Shriners opted to engage with local populations, it was sometimes legitimized as "jollification": "a team of burros and their Mexican drivers, their wagon partly filled with potatoes, several ladies and Nobles took possession and were photographed."59 Even as the words betray condescension, the fact that cameras were used to record such moments also asserted the self-absorbed superiority of the participants.

By the time the Shriner caravan reached Hawaii, its participants wearied by seasickness en route, the celebratory finale was heralded in erotic, exotic terms: "The mystic Inauguration of 'Aloha Temple' will be conducted with magnificent pomp and ceremony. Duty accomplished: There are

\footnotetext{
56 Ibid., 14.

57 Ibid., 20-22.

58 Ibid., 19.

59 Ibid., 24-25.
}

flower-crowned houris in this land, bronze beauties that shall dance before your divans until the senses are intoxicated. There will be other intoxicants: there will be yarn-spinning across the hookahs and coffee cups where Noble out-doeth Noble and truth hides its head in a hubble bubble. Aloha!" 60 While this bit of prose is incongruous but stereotypical Orientalism, the Shriner arrival in Honolulu also generated local newspaper coverage wherein the rhetoric is rather different. Three weeks of hospitality were planned at elite locations and souvenir $f e z$ headgear made "by native hands from the dried lahala used for the regular native hats" ${ }^{\prime \prime 1}$ were produced for the visitors. Clearly, there is a palimpsestic cultural encounter underway, permeated with both "Arab" charade and "Hawaiian" reception. While such reportage would offer rich insight into the polyglot environment that the Shriners encountered and complicated, I turn, instead, to the longer and deeper story beyond the headlines to acknowledge the costs and sustained accommodation of outsiders in the island chain. It is not a celebratory tale.

Over the course of the nineteenth century, Hawaii was subject to waves of missionary activity launched from East Coast institutions, as well as depredation, infestation, and invasion. ${ }^{62}$ The last

\footnotetext{
6o Ibid., 99.

61 Pacific Commercial Advertiser, Honolulu, March 13, 1901, 3. I thank Kailani Polzak for her nuanced advice on Hawaii and related traditions.

62 Studies of missionary and colonizing activities in Hawaii are numerous and most of them are written from outsider perspectives. A useful overview is Noenoe K. Silva's Aloha Betrayed: Native Hawaiian Resistance to American Colonialism (Durham: Duke University Press, 2004). Williams College Museum of Art's exhibition, The Field Is the World (2018), curated by Kailani Polzak and Sonnet Coggins, addressed critical issues with particular reference to photography and Williams College's role in mission activities. For one iteration of the missionary perspective, see Clifford Putney, Missionaries in Hawaii: The Lives of Peter and Fanny Gulick (Boston: University of Massachusetts Press, 2010), 1-11.
} 
decade had witnessed the overthrow of the Hawaiian monarchy, the American annexation of the island chain, and its formalization as a territory: that status lasted until statehood, in 1959. Viewed from this diachronic perspective, the caravan takes on a more insidious tone, a place-specific iteration of settler colonialism. It was not militarized but mission-driven and entrepreneurial, transpiring over decades and manifest in diverse ways. ${ }^{63}$ Spreading "proper" religious convictions and extending mercantile/political control was the proverbial two-edged sword, not unlike what happened in that other "Orient" under the American Board of Commissioners for Foreign Missions. In both cases, America's Manifest Destiny carried overtones of converting "heathen" populations and universalizing Christianity. ${ }^{64}$ The United States may not have deployed power as overtly as France did in North Africa, or as the Ottomans did in the Arabian Peninsula, but incursions were underway on the other side of the globe that defaced indigenous religion, language, social structures, cultural institutions, and practices over time. While I will look further at these issues below, I want to conclude this step in my argument simply by underscoring the rhetorical camouflage that I have detailed above. In effect, as the pious industrializing adventurers went West rather than East,

63 For terms, themes and structures, see Aimee Carrillo Rowe and Eve Tuck, "Settler Colonialism and Cultural Studies: Ongoing Settlement, Cultural Production, and Resistance," Cultural Studies/Critical Methodologies 17, no. 1 (2017), 3-13.

64 Cf. Edwards, "A Million and One Nights," in Edwards, Noble Dreams, Wicked Pleasures, 19-20. See Ussama Makdisi, Artillery of Heaven: American Missionaries and the Failed Conversion of the Middle East (Ithaca, NY: Cornell University Press, 2008); Janet Marquardt, "The Haystack Monument at Williams College," in Monumental Troubles: Rethinking What Monuments Mean Today, ed. Erika Doss and Cheryl Snay (Notre Dame, IN: Midwest Art History Society and the Snite Museum of Art, 2018), n.p.; and Fuad Shaban, Islam and Arabs in Early American Thought: The Roots of Orientalism in America (Durham: Acorn Press, 1991). the stereotypical Orient was mapped over a new terrain and a new topography was conquered. A particularized performance of Orientalism, this was creative cartography in the service of a young nation and it was just the first chapter in a longer story of globalization.

\section{From Garden to Country}

As the twentieth century unfolded, the United States became an incontrovertible power in transnational arena and the Shriners continued to augment that profile in inimitable public ways. Just two decades after the Hawaiian adventure and a few short years after World War I, a similar caravan ran East rather than West, to be welcomed in Washington D.C. with a parade down Pennsylvania Avenue. It was 1923. What is striking here is the theme of the whole event: "The Garden of Allah."

By this point, the Shrine had reached the upper echelons of society, including President Harding himself, now a fez-wearing member of the guild. ${ }^{65}$ The pilgrimage parade entailed months of planning and a huge budget; along the way, postcards, souvenirs, and other consumer items were available, urging constituents to "park your camel with Uncle Sam'l [sic]." The appropriate dress and accoutrements evoking the Orient—jewels, jackets, and scimitars-were de rigor, and commemorative keepsakes and postcards spread the word and kept the memories alive in the aftermath. ${ }^{66}$ While the formative impact that Masonic/Shriner activities had on the trajectories of American capitalism

65 Warren G. Harding's portrait appears, for example, in the commemorative album of the 1923 caravan along with an acknowledgement of his death shortly before the album was published in 1924. See Joseph Edgerton, Across the Burning Sands to the National Homecoming: The Pilgrimage 1923: The Official Story by Word and Picture of the Imperial Council Session of the AAONMS at Washington, D.C. (Washington, DC:AAONMS, 1923), xvii. Edwards, "Catalogue of the Exhibition," in Edwards, Noble Dreams, Wicked Pleasures, 216-23; cat. \#71-78. 


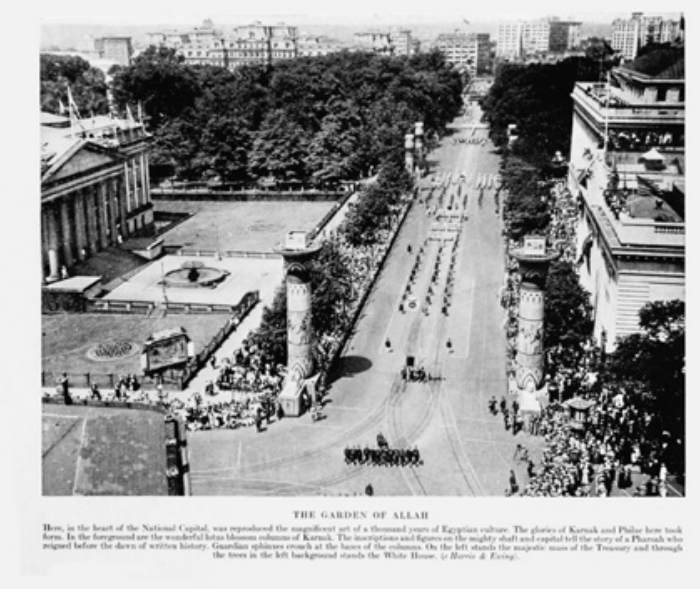

FIGURE 6.4 The Garden of Allah Pilgrimage down Pennsylvania Avenue, 1923. In Joseph Edgerton, Across the Burning Sands, n.p.

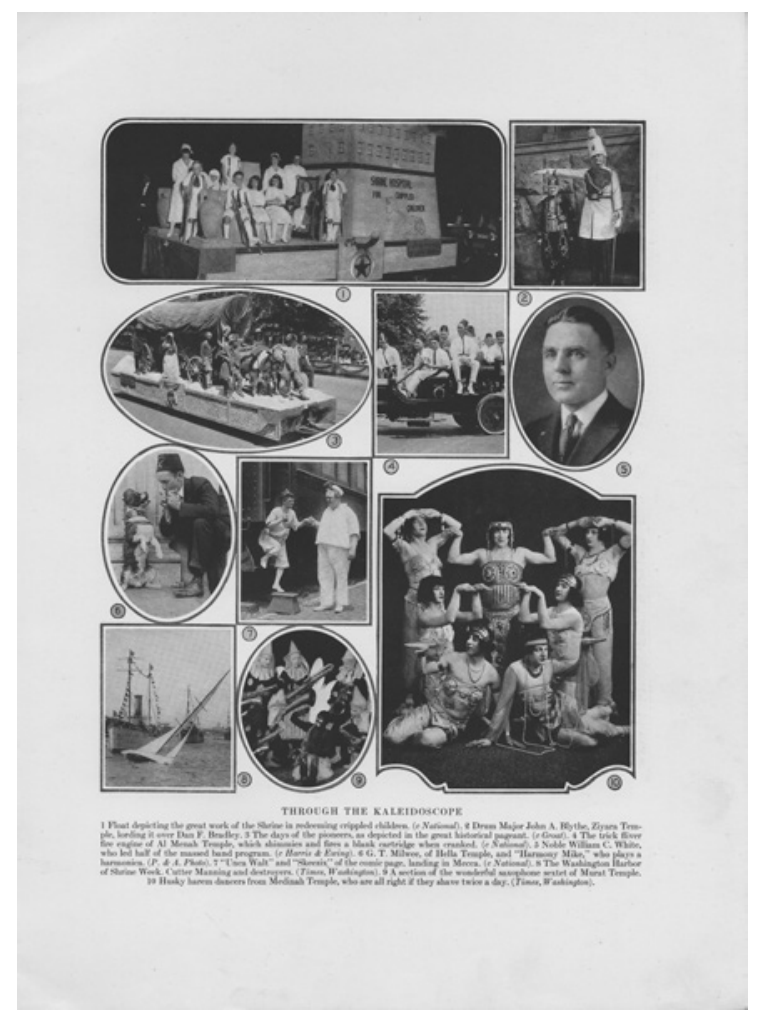

FIgURE 6.5 An "Oriental Princess," "Baghdad Clowns," Cleopatra, "Queen of the Shrine," and "Harem Dancers from Medinah." In Joseph Edgerton, Across the Burning Sands, p. 136. has been documented elsewhere, ${ }^{67}$ I would like to focus more narrowly here on the material evidence that remains from the caravan, in the form of photographs and stories in Joseph Edgerton's leather bound album, an artifact currently in the collections of the Chancellor Robert R. Livingston Masonic Library in New York City.

The simple choice to assemble such a volume is itself an act of commemorative self-fashioning whereby key patrons and participants are enshrined and pivotal moments are documented for posterity. The pilgrimage is a compelling tale beginning with a preface by Charles Warner about "The Garden of Allah" and a contribution by President Warren Harding entitled "True Fraternalism." 68 In his opening statement, Warner sets the stage in a manner reminiscent of Hichens' rhetoric: "the Garden of Allah is unknown to the senses ... its atmosphere is the quiet, ineffable purity under the dome of the oak leaf beneath the snow where the arbutus dwells. Its music is the harmony of the silent hand of conscience. It is the heart of God."69 Thereafter, the caravan is rendered as an adventure in chapters, accompanied by pictures and evocative titles: "Of the Camels Who Came Not out of the West," "East Breathes a Touch of Magic," "The Trek of the Gasoline Camels," and "The Red Sea Inundates the Capital." Along the way, the celebration of American technology and industry is a prominent theme again, this time tied to automobile culture and electrical delights. At the culminating event, Washington D.C. was transformed with "the most conspicuous scheme of decoration ever attempted in this country," with lighting that "employed 37,00o Westinghouse spray-colored lamps, the first time this type of bulb had been used for out of door decoration. The electric features alone cost $\$ 50,000 . " 70$

If the caravan celebrated American modernity for its own sake, the overland pilgrimage to the

67 Nance, How the Arabian Nights Inspired the American Dream, 19-50.

68 See Edgerton, Across the Burning Sands, xiv.

69 Ibid., xiii.

70 Ibid., 80. 
capital was recounted in exoticizing terms, with unparalleled views and topographical wonders of the American landscape extolled with Orientalizing enthusiasm. Nor was the rhetoric confined to sightlines; rather, it stretched to capture embodied experience effusively. For example, the travelers were particularly "impressed by the desolate beauty of the Painted Desert ... in which they counted sands of nineteen different colors. Here they saw two desert whirlwinds and were caught in the tail end of a sandstorm, when they emerged feeling like true Arabs." ${ }^{71}$ Seeing the desert, feeling the desert, and coming out changed were electrifying moments, demanding description in evocative trope. In this way, direct experience is conveyed vividly, knitting together familiar stereotype and palpable feeling, imagined place and traversed terrain.

Arriving in the nation's capital thereafter was deemed an extension of that same exotic topography in the commemorative album. The parade route (fig. 6.4) is termed "the Road to Mecca" and is documented photographically, with important (albeit non-Arab) sites along the way, including the Library of Congress, the White House, and the Washington Cathedral. Images of people (fig. 6.5) complement the architectural milestones, encompassing a wide range of characters, serious and otherwise: John Phillip Sousa, ${ }^{72}$ "an Oriental Princess," "Baghdad Clowns," and Cleopatra, "the Queen of the Shrine." "Harem Dancers from Medinah" are there as well, indicative of the absurd masquerading entertainments in which Shriners indulged. ${ }^{73}$ Such a collage captures a group identity visually, so that subsequent generations might deploy that past as preface for ongoing Masonic philanthropy. I turn away now from this zenith of institutionalized Shrine activity to

\footnotetext{
71 Ibid., 110.

72 John Philip Sousa was a renowned composer of band music who wrote "Nobles of the Mystic Shrine March," dedicating it to the Almas Temple in 1923. Cf. Edwards, "Catalogue of the Exhibition," in Edwards, Noble Dreams, Wicked Pleasures, fig. 72.

Ibid., 218-20 and figs. 71-78.
}

consider a single individual therein, whose story figures in the spaces between the United States and the Arab world, via Hawaii.

\section{Who Is in Charge Here?}

James Sutton ("Sunny Jim") McCandless was Imperial Potentate of the Shrine and Venerable Master of Lodge of Perfection from 1922 to 1924, as well as one of the founders of the Shriners Hospitals for Children in Honolulu. His biography is telling. Having joined the Aloha Temple of Freemasonry in 1904 (three years after the Shriner caravan to Honolulu), he was instrumental in the conception and staging of the Garden of Allah Caravan, so his portrait prefaces that commemorative album. Not surprisingly, McCandless' exalted Masonic status was congruent with his role in Hawaiian industry and history over the course of decades. He had moved to Hawaii in 1880 at the age of 25 , whereupon he and his brothers founded a drilling company, constructing over 700 artesian wells across the island and thus helping to foster, support, and irrigate the sugar and pineapple plantations central to the Hawaiian economy. From such commercial embeddedness, the McCandless brothers participated actively in the overthrow of the Hawaiian monarchy in 1893 and in the cascading ramifications thereafter. ${ }^{74}$ While time and space preclude exploring these major events in island history, suffice it to say that the entanglement between the McCandless family, Freemasonry and the Shrine, and the American nation was sustained and formative.

And what of "the Garden of Allah"? James McCandless never set foot in the Arab world, but his carefully-staged pilgrimage invoked Islam and its

Peter T. Young, "Sunny Jim, John and Link," Ho'okuleana (blog). 2014. http://totakeresponsibility.blogspot.com/ 2014/og/sunny-jim-john-and-link.html?m=1; for biography, see also the official website of the Honolulu lodge at http://honolulufreemasons.org/. 
sacred terrain to provide a very public experience for his fellow Masons. How to decode this invocation of a globally-disseminated faith? Is this spiraling path of world-making a matter of Orientalism, or have we gotten lost in the wake of the Shriners? In response, I circle back to my starting point-Gérôme's The Snake Charmer-to ask if its iconic character and the Saidian ideology that it conjures are pertinent for any other audiences. It would seem so. Paul Rich and Guillermo De Los Reyes have asserted the toxic character of the Shrine and its impact in the world of Islam and other arenas of religious conviction. ${ }^{75}$ Decrying the Nobles' practices as "Orientalist Fraternalism," the authors document diverse Shrine centers in the Middle East and the resentment that the order has inspired for disrespectful appropriation of ritual and belief. If Shrine activities have engendered a range of responses in the original landscapes of monotheism, however, neither Islam nor Christianity was indigenous to Hawaii. ${ }^{76}$ By extension, how Shrine behaviors, in particular, collided or colluded with local religious and spiritual practices in the early twentieth century would be a case study unto itself. Clearly, however, location matters. Clearly, too, that thing, "Orientalism," is a transferable heuristic tool as diverse selves fashion worlds to occupy and others are cast in supporting roles.

75 As pointed out by Rich and Los Reyes, "to Muslims, it is a ritual monster founded on cultural plagiarism" (9). The authors argue further that the intrusion and appropriation of Shriner rituals also impinges on Christian denominations and other faith bodies and call it a "surrogate religion" (17). Paul Rich and Guillermo De Los Reyes, "The Nobles of the Shrine: Orientalist Fraternalism," Journal of American Culture 21, no. 4 (Winter 1998): 9-19.

76 Mission efforts transformed island landscapes and entailed construction of institutions, establishment of literacy, and indoctrination. Cf. Silva, Aloha Betrayed, 30-35.

\section{8}

\section{So, Where Are We?}

At this juncture, then, I return to the continental United States to contextualize some emerging institutions with reference to themes I have laid out above-Orientalism, religion, museum culture, and nation-building. First, I invite the reader to consider the synchronicity of the Garden of Allah pilgrimage in 1923 with the growth of Islam on American soil. Admittedly, a pivotal event had occurred earlier, on September 20, $1893 \cdot{ }^{77}$ At the first World's Parliament of Religions transpiring in downtown Chicago, Alexander Russell Webb gave a talk, "The Spirit of Islam," delivered to a packed house. It was an audience of primarily Protestants along with representatives of other faiths. In that speech, Webb sought to emphasize the broader monotheistic tradition and thereby encourage greater understanding of the religion to which he had converted during his ambassadorial tenure in the Philippines: "The system is one that has been taught by Moses, by Abraham, by Jesus, by Mohammad, by every inspired man the world has ever known. You need not give up Jesus, but assert your manhood. Go to God!"78 From that vantage point and with seed funds from India, he opened the Moslem World Building on W. 2oth Street in New York as his headquarters and published a journal to foster the religion in the United States.

Over time, then, Detroit, Michigan, came to be called "a microcosm of Islam in America."79 There,

77 I present the preface to this event elsewhere. See Holly Edwards, "Yankee Mahomet," in The Image of the Prophet between Ideal and Ideology: A Scholarly Investigation, ed. Christiane J. Gruber and Avinoam Shalem (Berlin: De Gruyter, 2014), 337-56. Also relevant are Shaban, Islam and Arabs in Early American Thought, and Timothy Marr, The Cultural Roots of American Islamicism (New York: Cambridge University Press, 2006).

78 Umar F. Abd-Allah, A Muslim in Victorian America: The Life of Alexander Russell Webb (New York and Oxford: Oxford University Press, 2006), 274.

79 Mucahit Bilici, Finding Mecca in America: How Islam Is Becoming an American Religion (Chicago: University of Chicago Press, 2012), 15-20. 
the first mosque in America was built in 1921, just two years before the Shriner caravan to Washington: it was established in Highland Park by Lebanese Sunni immigrants. In 1930, the Nation of Islam was founded by Wallace D. Fard and led by Elijah Muhammad, its first "temple" being anchored in Detroit. I mention only these two disparate benchmarks to suggest the variegated nature of American Islam and, by extension, to underscore the spiraling scope of the story I have told here. Clearly, Shriner masquerade is not Islam, but both are headline news in the 1920s America and both are "Arab" variables in a broader picture, the rich mélange of identities and institutions coalescing at the time around the globe. Now, I would look beyond that cover story to spotlight another cast of characters active between Detroit and Washington and consider how they figure in the emergence of the American nation.

On May 9, 1923, just a few short weeks before the Garden of Allah pilgrims paraded down Pennsylvania Avenue, the Freer Gallery of Art opened on the Mall. At that time, it was the first art museum on the Smithsonian campus and the culmination of an elite collaboration between Detroit businessman Charles Lang Freer and President Theodore Roosevelt that had begun years before. ${ }^{80}$ The two men had recognized in Asia an emerging force deserving of study and respect and, in 1906, Freer deeded to the nation his burgeoning array of Asian and American art. By exploring the differences in materials from around the world, the Freer Gallery of Art would unite, in Freer's own words, "modern work with masterpieces of certain periods of high civilization harmonious in spiritual suggestion." ${ }^{81}$ That enterprising traveler and connoisseur thus augmented museum culture ${ }^{82}$ in

8o Thomas Lawton and Linda Merrill, Freer: A Legacy of Art (New York: National Arts Club, 2007).

81 "History and Building," Freer Gallery of Art, accessed April 1, 2019, https://www.freersackler.si.edu/about/ about-the-freer-gallery-of-art/.

82 Comparing the formation of the Freer collections and that of the Metropolitan Museum of Art collections the nation's capital along globalizing lines, collapsing time and space around extraordinary artifacts for the edification of future generations. ${ }^{83}$

While it is tempting to dive deeper still into the web of worlds that Freer occupied-surely his railroad car business would have directly or indirectly figured in the 1901 Shriner caravan journey across country-broader issues deserve acknowledgement. It is important to underscore that, while Freer's collections derived from that ambiguous place, the Orient, his attitudes cannot be glibly equated with Orientalism in the Saidian sense, nor was his "Orient" the same as that of Robert Hichens. Indeed, that place was morphing in collective imaginations and Freer's travels were centered further east, in China and Japan. Moreover, his methodical acquisition of artifacts was but one part of a larger phenomenon of nationbuilding by means of museum-building. ${ }^{84}$ The monument that Freer founded (and others thereafter) has enshrined objects and defined cultures in endlessly protean ways, ${ }^{85}$ but in the early twentieth century many of those things had yet to be taxonomized as "art," or natural history, or

would enhance the scope of this project. Cf. Priscilla Soucek, "Building a Collection of Islamic Art at the Metropolitan Museum, 1870-2011," in Masterpieces from the Department of Islamic Art in the Metropolitan Museum of Art, ed. Maryam D. Ekhtiar, Priscilla P. Soucek, Sheilla R. Canby, and Navina Najat Haidar (New York: Metropolitan Museum of Art, 2011), 2-9. See also Richard H. Collin, "Public Collections and Private Collectors," American Quarterly 46, no. 3 (1994): 448-61.

83 That those future generations are now also challenged to de-colonize museums and revise "art history" accordingly is the ironic quandary of globalized visual culture.

84 Tony Bennett, The Birth of the Museum: History, Theory, Politics (London: Routledge, 1995).

85 The work that museums do is a field of study unto itself. Cf. Steven Conn, Do Museums Still Need Objects? (Philadelphia: University of Pennsylvania Press, 2010), esp. 86-137, and Daniel Sherman and Irit Rogoff, Museum Culture: Histories, Discussions, Spectacles (Minneapolis: University of Minnesota Press, 1994). 
"other." ${ }^{86}$ At that formative moment, Freer's approach was globalizing, utopian, and aestheticallydriven, working to re-frame objects from Asia as fine art in the U.S.A. This was a collectivizing vision at a tumultuous time in history.

While I make no pretense of tracing that story here, I want to return to a basic premise of this chapter in conclusion. "Art" is a category of things that wields vast power in millennial circumstances, the material evidence of illustrious heritage, sophistication and political legitimacy. In grandlyconceived exhibition spaces, "art" is more than mere stuff. It offers sanctuary and arsenal at once. Contemplating a masterpiece can be a sustaining, inspiring, and even therapeutic experience; owning and exhibiting that masterpiece can be a powerful stance. Museums in the Arab world are currently wielding this tool, performing individuation diversely in response to oil wealth and rapid modernization. Thus, mobilizing the past for present and future purpose, citizens, collectors, and curators are proactive cartographers in global visual culture even as the "Orient" morphs in the minds of others.

\section{$9 \quad$ Epilogue}

As this tale has wandered from place to placefrom the Orient to the Arabian Desert to the Garden of Allah, and from imaginings to artifacts to institutions-many boundaries have been

86 The institutional trajectory of the Jenks Museum at Brown University is revealing of museum histories, taxonomies, enshrined things, and institutional structures. See Steven Lubar, Inside the Lost Museum: Curating Past and Present (Cambridge, MA: Harvard University Press, 2017). crossed and also drawn. Nations have emerged on the world stage and cultural identities have taken shape with reference to art, collections, and historical traditions. Such is the power of things for the fashioning of self. And so, the path is neither simple nor linear nor even really topographical. Rather, it has been a globalizing route through a multi-centric and heterochronic landscape, trailing behind some powerful pictures and stretching from somatic to spiritual experience. Gérôme's painting bears little resemblance to Cassidy's lithograph, but both martial a certain "realism," reducing the world to manageable metaphors and graspable ideas by visual means. That, I would argue, is what things do - create and sustain a habitable setting or place for generations to occupy and build on. Producing and deploying such images, either literally or figuratively, is one way by which the world is mapped and imaginative stories are told, shaping a conducive arena for the future to unfold.

How inclusive or trustworthy the resulting tales are is, of course, a matter of opinion, even as the force and agency of art depends on how it is wielded and by whom. In our technologically-assisted world, images are metastatic and metathetic things. No longer just mechanically-reproduced, now they are multiplied, mediated, and marketed online in a collage that offers myriad Arab places for the delectation of others. Within that visuality, Gérôme's painting is reproducible but not replaceable; its uniqueness is amplified by its gilt frame and enshrined status in a private collection. By contrast, Asa Cassidy's Garden of Allah is available for purchase, poster size and in the color of your choice, from Wal-Mart. What digitized desert voices murmur to millennial consumers about the Arab world, however, will vary considerably with time, place, and players. 